\title{
INTRAOPERATIVE CELL SALVAGE DURING RADICAL PROSTATECTOMY: A SAFE TECHNIQUE FOR JEHOVAH'S WITNESSES
}

\author{
ALAN M. NIEDER, MICHAEL A. SIMON, SANDY S. KIM, MURUGESAN MANOHARAN, \\ MARK S. SOLOWAY
}

Department of Urology, University of Miami School of Medicine, Miami, Florida, USA

\begin{abstract}
Radical retropubic prostatectomy (RRP) is an operation historically associated with the potential for significant blood loss. Patients who refuse a blood transfusion, such as Jehovah's witnesses, may be only offered radiation therapy as potentially curative treatment for prostate cancer because of the potential for a transfusion. Intraoperative cell salvage (IOCS) is an effective blood management strategy for patients who are not willing to accept predonated autologous or allergenic blood. We present our management for Jehovah's Witness patients with clinically localized prostate cancer, emphasizing our blood management approach. This is the first such report.
\end{abstract}

Key words: prostate cancer, prostatectomy, cell salvage, Jehovah's witness

Int Braz J Urol. 2004; 30: 377-9

\section{INTRODUCTION}

Radical retropubic prostatectomy (RRP) is an operation, which may be associated with significant blood loss. Variability in anatomy, difficulty in controlling the dorsal venous complex, nerve sparing vs. non-nerve sparing, obesity, and surgeon experience may all affect the estimated blood loss (EBL). The mean EBL during RRP has been reported up to 1800 $\mathrm{mL}$ in previous series (1). Even in contemporary series, the EBL ranges from $770 \mathrm{~mL}$ (2) to $1575 \mathrm{~mL}$ (3). Some patients may require a blood transfusion, either allogeneic or autologous. Different means of managing blood loss include preoperative donation of autologous blood (4), preoperative recombinant erythropoeitin injection (5), intraoperative hemodilution (6), and intraoperative cell salvage (IOCS) (7). IOCS is an attractive blood management strategy since it is relatively inexpensive and prevents the risks associated with allogeneic blood transfusion such as viral infection. For those patients who refuse any blood transfusions on religious grounds, IOCS may by the only safe method of blood management during RRP.

Many oncologic surgeons have been reluctant to utilize IOCS because of the theoretical risk of tumor dissemination. Prostate cancer is unique since there is a sensitive marker, PSA, to detect recurrence. Davis et al. (8) published our institutional experience with IOCS between 1992 and 1998 and reported no shortterm increased risk of biochemical recurrence among 408 patients. We now present 3 cases of Jehovah's witnesses who underwent RRP utilizing IOCS for management of intraoperative bleeding.

\section{CASE REPORTS}

\section{Case 1}

A 53-year-old gentleman was referred to our institution with clinical stage T1c prostate cancer. The patient's PSA was $4.5 \mathrm{ng} / \mathrm{mL}$, and a prostate biopsy 
revealed Gleason 6 prostate cancer in 4 of 10 cores. The prostate was $30 \mathrm{~g}$ and soft without nodules. The patient had previously been seen by another urologist who refused to perform a RRP because the patient's avowed refusal of all blood products, secondary to his religious beliefs as a Jehovah's Witness. The patient was offered radiation therapy; however, he preferred RRP.

The patient underwent a bilateral nervesparing RRP without complications. His EBL was $1500 \mathrm{cc}$ and he received $625 \mathrm{cc}$ of cell-salvaged blood intraoperatively. His pathology revealed a pT2b prostate cancer, Gleason 6 with negative margins. He was discharged home on postoperative day (POD) 1 and his catheter was removed on POD $7 . \mathrm{He}$ is continent and voiding well 9 months postoperatively.

\section{Case 2}

A 45-year-old Jehovah's Witness was referred to our institution with clinical stage T1c prostate cancer (PSA 8.5, Gleason 6, small focus, 50g soft prostate without nodules.). He refused any blood transfusion but accepted the use of IOCS. The patient underwent a bilateral nerve-sparing RRP under spinal anesthesia without complications.

IOCS was available during the case; however, since the EBL was $400 \mathrm{cc}$ he did not receive any cellsalvaged blood. His pathology revealed a small focus of Gleason 6 prostate cancer, stage pT2b with negative margins. His PSA is undetectable and he is continent 6 months postoperatively.

\section{Case 3}

A 68-year-old Jehovah's Witness was referred to our institution with clinical stage $\mathrm{T} 2 \mathrm{~b}$ prostate cancer (PSA 10, Gleason 7 in multiple cores, $40 \mathrm{~g}$ prostate with bilateral induration). He refused any blood transfusion but accepted the use of IOCS. The patient underwent a bilateral nerve-sparing RRP under spinal anesthesia without complications. IOCS was available during the case; however, the EBL was 300 cc and he did not receive any cell-salvaged blood. His pathology revealed Gleason 7 prostate cancer, stage pT2b with negative margins. His PSA is undetectable and he is continent 3 months postoperatively.

\section{COMMENTS}

Oncologic surgeons have been hesitant to embrace IOCS primarily because of a theoretical risk of tumor dissemination. Ward et al. demonstrated that malignant prostatic cells could be identified in cytological washings during RRP (9). However, several studies have demonstrated the safety of IOCS during urological oncology procedures $(10,11)$. We do not believe that there is a significant, if any, risk of tumor dissemination from IOCS. Davis et al. demonstrated no difference in the risk of biochemical recurrence with the use of IOCS in 408 patients undergoing RRP at our institution (8). Eighty-seven patients who received cell-salvaged blood, 264 who received only an autologous transfusion, and 57 who received no transfusions were compared. Biochemical recurrence was detected in 67 patients $(16 \%)$ and was not significantly associated with the method of transfusion (chi-square, $p=0.784$ ). In a more updated analysis involving over 1,000 patients who underwent RRP at the University of Miami School of Medicine, the 5-year PSA-recurrence risk for those who did and did not receive cell-salvaged blood was $15 \%$ and $18 \%$, respectively $(p=0.76)$. In this large series, the risk of receiving an allogeneic transfusion was $0.9 \%$.

Options for management of blood loss in Jehovah's Witnesses are limited. Though there are different levels of orthodoxy, most Jehovah's Witnesses will neither accept autologous nor allogeneic blood transfusion, even at the risk of hypotension and death. Moskowitz et al. reported on their use of IOCS and hemodilution to manage a Jehovah's Witness patient with a renal cell carcinoma and a supradiaphragmatic inferior vena cava thrombus (12). Other blood management strategies that are acceptable for Jehovah's Witnesses include preoperative erythropoietin, which has been shown to be safe and effective for patients undergoing RRP (13). In our cases, the patients declined to donate autologous blood preoperatively but agreed to the use of IOCS. Though the risk of receiving a transfusion during RRP is low at our institution, it is still present. 
The utilization of IOCS is acceptable for many Jehovah's Witnesses and allows these patients to undergo elective procedures safely and confidently while minimizing the risk of hypotension related to bleeding.

\section{CONCLUSION}

We present the first cases in the literature describing the use of IOCS during RRP for Jehovah's Witnesses. IOCS enables these patients to safely undergo RRP without the need for blood transfusion. We do not believe that there is an increased risk of tumor dissemination by utilizing IOCS during RRP. We have IOCS available for RRP and other urologic oncology operations in which there is a potential for significant blood loss.

\section{REFERENCES}

1. Moul JW, Sun L, Wu H, McLeod DG, Amling C, Lance $\mathrm{R}$, et al.: Factors associated with blood loss during radical prostatectomy for localized prostate cancer in the prostate-specific antigen (PSA)-era: an overview of the Department of Defense (DOD) Center for Prostate Disease Research (CPDR) national database. Urol Oncol. 2003; 21: 447-55.

2. Goh M, Kleer CG, Kielczewski P, Wojno KJ, Kim K, Oesterling JE: Autologous blood donation prior to anatomical radical retropubic prostatectomy: is it necessary? Urology. 1997; 49: 569-73; discussion 574.

3. Lance RS, Freidrichs PA, Kane C, Powell CR, Pulos E, Moul JW, et al.: A comparison of radical retropubic with perineal prostatectomy for localized prostate cancer within the Uniformed Services Urology Research Group. BJU Int. 2001; 87: 61-5.

4. Goodnough LM, Grishaber JE, Birkmeyer JD, Monk TG, Catalona WJ: Efficacy and cost-effectiveness of autologous blood predeposit in patients undergoing radical prostatectomy procedures. Urology. 1994; 44: 226-31.

5. Rosenblum N, Levine MA, Handler T, Lepor H: The role of preoperative epoetin alfa in men undergoing radical retropubic prostatectomy. J Urol. 2000; 163: 829-33.

6. Monk TG, Goodnough LT, Brecher ME, Pulley DD, Colberg JW, Andriole GL, et al.: Acute normovolemic hemodilution can replace preoperative autologous blood donation as a standard of care for autologous blood procurement in radical prostatectomy. Anesth Analg. 1997; 85: 953-8.

7. Gray CL, Amling CL, Polston GR, Powell CR, Kane CJ: Intraoperative cell salvage in radical retropubic prostatectomy. Urology. 2001; 58: 740-5.

8. Davis M, Sofer M, Gomez-Marin O, Bruck D, Soloway MS: The use of cell salvage during radical retropubic prostatectomy: does it influence cancer recurrence? BJU Int. 2003; 91: 474-6.

9. Ward JF, Nowacki M, Sands JP, Conner RJ, Huisman TK: Malignant cytological washings from radical prostatectomy specimens: a possible mechanism for local recurrence of prostate cancer following surgical treatment of organ confined disease. J Urol. 1996; 156: 1381-4; discussion 1384-5.

10. Klimberg I, Sirois R, Wajsman Z, Baker J: Intraoperative autotransfusion in urologic oncology. Arch Surg. 1986; 121: 1326-9.

11. Hart OJ 3rd, Klimberg IW, Wajsman Z, Baker J: Intraoperative autotransfusion in radical cystectomy for carcinoma of the bladder. Surg Gynecol Obstet. 1989; 168: 302-6.

12. Moskowitz DM, Perelman SI, Cousineau KM, Klein JJ, Shander A, et al.: Multidisciplinary management of a Jehovah's Witness patient for the removal of a renal cell carcinoma extending into the right atrium. Can J Anaesth. 2002; 49: 402-8.

13. Nieder AM, Rosenblum N, Lepor H: Comparison of two different doses of preoperative recombinant erythropoietin in men undergoing radical retropubic prostatectomy. Urology. 2001; 57: 737-41.

Received: September 29, 2004 Accepted: October 20, 2004 